\title{
A Public Policy based on fiscal incentives for supporting companies to Invest in Innovation Projects - The Law of Good
}

\author{
Dalva Magro $^{1-3}$, Roberto da Piedade Francisco ${ }^{2-3}$ \\ ${ }^{1}$ State University of Santa Catarina, Innovation Department, 88.010-320 - Florianópolis, SC, \\ Brazil \\ dalva.magro@inescbrasil.org.br \\ ${ }^{2}$ Federal University of Goiás, Department of Industrial Engineering, 74.968-755 - Aparecida \\ de Goiania, GO, Brazil \\ robertopiedade@gmail.com \\ $3^{3 *}$ Institute of System Engineering, Research and Development of Brazil, Innovation \\ Management Department, Santos, SP, 11.055-300 Brazil
}

\section{Policy Letter}

\begin{abstract}
Creativity, technical knowledge and financial resources, whether public or private, are three very important subjects to encourage technological innovation. Public policies on fiscal incentives fostering the increase of investment of financial resources for RD\&I projects are particularly needed in developing countries. Therefore, this article aims to inform about the legal and bureaucratic procedures for the execution of research projects developed by partnerships between a company and an Institute of Science and Technology (i.e. ICT) applying the incentives of Brazilian Federal Law No. 11,196/2005 - Law of Good. This letter describes all the legislation that supports such incentives and outlines the needed accounting procedures to be performed. As a result, a demonstration on research expenditures and the impact on the reduction of income taxes is performed regarding to the following Brazilian income taxes: Income Tax (i.e. IRPJ) and Contribution on Net Income (i.e. CSLL), levied to the Brazilian taxpayers.
\end{abstract}

Keywords. Income tax, innovation, public policy, research and development, tax accounting.

\section{The Law of Good}

Public policies that can improve technological knowledge are necessary to increase competitiveness of developing countries. Particularly, tax incentive policies are necessary to increase investments in innovative technologies because the tax burden is very high, reducing the financial resources available to invest.

The Law of Good was created in 2005 to motivate Brazilian companies to invest in Research, Development and Innovation (i.e. RD\&I). Such law has been increasingly used by companies that opt for the taxation called Real Income, which is the accounting calculation referring to the company financial results considering some criteria of the 
tax legislation. By 2012, more than 1,000 companies have qualified for the incentive which includes deductions from the Brazilian taxes called IRPJ (i.e. Income Tax) and CSLL (i.e. Social Contribution on Net Income), as well as differentiated rules for the depreciation of machinery and equipment.

\subsection{Tax Incentives Regulation}

The legislation that regulates the tax breaks for RD\&I projects is described in the Law No. 11,196/2005, Chapter III, and the Decree No. 5,798/2006, and the Normative Instruction No. 1,187/2011 of the Brazilian Federal Internal Revenue Service (IRS).

Specifically, chapter III, articles 17 to 21 , shows the fiscal incentives for technological innovation that companies must meet to obtain the benefits of the law, as follows:

- Art. 17. The corporate may take advantage of the following tax incentives:

I. Deduction, for purposes of determination of the net income, of the amount corresponding to the sum of the expenses with RD\&I incurred during the determination period if classifiable as operating expenses by the tax legislation on income tax (i.e. IRPJ) or as payment defined in the paragraph 2 of this article;

II. Reduction of 50\% (fifty percent) of the Tax on Industrialized Products (i.e. IPI) on equipment, machinery, electronic devices and instruments, as well as spare parts and tools accompanying such goods for RD\&I projects;

III. Full depreciation of new machines, equipment, electronic devices and instruments, in related to the year of acquisition, intended for use in research activities and development of technological innovation, for purposes of calculating the IRPJ and CSLL;

IV. The accelerated amortization in the determination period, for purposes of calculating IRPJ, by deduction as an operating cost or expenses related to the acquisition of intangible assets, exclusively related to the activities of a RD\&I project, classified in the deferred assets of the beneficiary.

- Art. 18. In accordance with Art. 17, paragraph 1, of this Law and with paragraph 6 , the financial amounts transferred to microenterprises and small companies referred to in Law No. 9,841/1999, intended for the execution of RD\&I projects of interest to the legal entity that paid the services may deduct the operating expenses, even if the legal entity receiving those amounts is interested in the economic results of the resulting product.

- Art. 19-A. The company may exclude from the net income the expenditures carried out in the RD\&I project executed by a ICT, for purposes of calculating the income tax payable and for using as default value for calculating the CSLL (...).

- Art. 20. For the purposes of this Chapter, the amounts related to expenditures incurred in facilities and acquisition of electronic devices, machinery and equipment, intended for use in research and technological development projects, metrological tests, technical standardization and conformity assessment, applicable to products, processes, systems and personnel, authorization for registrations, licenses, homologations and their related forms, as well as procedures for the protection of intellectual property, may 
be depreciated or amortized under current legislation, and the balance not depreciated or not amortized can be excluded in the determination of the income tax payable, in the determination period in which its use is completed.

- Art. 21. The federal government, through the agencies for funding science and technology, may subsidize the remuneration of researchers, both graduated and post-graduated, employed in activities of technological innovation in companies located in the Brazilian territory, using a specific regulation.

In addition, the company must meet the following requirements:

- be taxed under the Real Income regime;

- should have no debts with the Brazilian federal income taxation;

- should have reached taxable income in the period under consideration.

\subsection{Accounting Procedures}

Even more, there are difficulties to be faced by companies in relation to the accounting procedures of such fiscal incentives. For example, some difficulties were found in the execution of bureaucratic procedures to access the tax breaks when RD\&I projects are submitted to the public calls of the Ministry of Science, Technology and Innovation (i.e. MCTI). Such calls invite interested parties to present RD\&I projects involving scientific research and technological innovation aiming to promote and encourage developing innovative processes and products. In fact, researchers and companies find difficulties in understanding how resources used for research and innovation can be used to earn such fiscal incentives.

Therefore, we intend to unveil these procedures of Law No. 11,196 with a practical example that considers fictitious amounts to calculate what percentage can be deducted from the total taxable income.

\section{Process procedures for obtaining the incentives for RD\&I}

Over time this law was better understood and, simultaneously, new institutions of science and technology (ICT) emerged in Brazil assuming an increasingly important role in RD\&I projects. Consequently, it is particularly relevant that the Law of Good has motivated partnerships between ICTs and companies classified in the Real Income regime to carry out RD\&I projects.

In the Law text, the government defined what an RD\&I activity is by using the concepts of the Frascati Manual (OECD, 2013) which is a methodology for surveys on research and experimental development that intends to establish what is and what is not part of a RD\&I project. Particularly, the Law characterize research projects as follows:

- Basic or fundamental research: consists of experimental or theoretical works carried out mainly with the aim of acquiring new knowledge about the fundamentals of observable phenomena and facts, without considering an existing application or specific use.

- Applied research: consists in the accomplishment of original works for purposes of acquiring new knowledge. It is primarily focused on a goal or specific 
practical purpose.

- Experimental development: consists of performing systematic work, based on pre-existing knowledge, obtained through research and/or practical experience, to manufacture new materials, products or devices, processes, systems and services or to improve considerably the existing ones.

In summary, the Law defines technological innovation as the design of a new product or manufacturing process, as well as the aggregation of new functionalities or characteristics to the product or process that implies incremental improvements and effective gain of quality or productivity, resulting in greater competitiveness.

Companies should submit the RD\&I project to CAPES - the government agency responsible for evaluating research programs in Brazil - so that it can be evaluated and then recommended if the evaluation criteria are fully satisfied, and then can use such tax incentives. This process is regulated by the Call for Proposals CAPES MEC/MDIC/01/2007. This Public Call is an initiative to promote the research and development of innovative processes and products, with a view to public welfare, to the progress of science, to the country's technological autonomy, providing a strong link between the ICTs and companies. The main objective is to improve the national and regional business environment, as well as to stimulate the acquisition of industrial and intellectual property rights by ICTs and by national companies, by granting fiscal incentives to scientific and technological research projects. Additionally, another objective of this call is to better estimate or share costs, to reduce the technological risk of innovation and to stimulate an expansion of innovation activities in the Brazilian productive environment, as well as to prioritize proposals in line with the following actions of the Industrial, Technological and Foreign Trade Policy - PITCE:

- horizontal actions: increasing cooperation between ICTs and companies, increasing competitiveness through innovation, consolidation and promotion of technologies in the productive chains, reducing the cost of research and technological development activities;

- strategic options: semiconductors and software, drugs and medicines, and capital goods;

- new trends: biotechnology, nanotechnology, biomass and alternative energies.

The proposals are analyzed in two stages: (i) pre-qualification and (ii) evaluation of merit, within ninety days counted from the electronic submission. After this, the decisions of the Committee shall be published in the Official Gazette of the Brazilian Government, identifying the approved and rejected proposals for purposes of requesting reconsideration. In such a case, the Committee may appoint a new ad hoc consultant to support the assessment of the request for reconsideration, if appropriate.

After the publication of Ministerial Order, the corporate entity may exclude from the net income the expenses incurred to finance the RD\&I project for the purposes of calculating the tax base of IRPJ and CSLL. It is noteworthy that it is only possible if the project was previously approved in accordance with the Art. 19-A, Law No. $11,196 / 2005$ referred above, as well as the applicable tax regulations and the Public Call rules. The exclusion of expenses shall be carried out in accordance with the disbursement schedule provided for the execution of the project. The corporate entity is obliged to provide information to MCTI about its technological research programs 
in accordance with the Ministry regulations by July 31 of the project ongoing year. In addition, there are specific topics that are supported by the Law of Good, such as:

- Materials, supplies and services used for product improvements and manufacturing processes, including obtaining quality certificates;

- Expenses with salary and other labor costs related to employees or outsourced persons that perform activities related to RD\&I;

- Actions to optimize the use of resources for the projects;

- Systems and software developed by the company itself or partially outsourced.

Then, once these tax breaks are authorized, companies are supposed to be prepared for the bureaucratic procedures that need to be well performed to get such tax incentives. Although the purposes and requirements defined in this law seem simple and clear, it turns out that bureaucratic procedures in Brazil are often quite complex and complicated due to a highly bureaucratic public administration.

\section{A practical application of the Law of Good}

In general, the taxation in the Real Income regime applies to: (i) large companies, (ii) certain segments of the economy which use fiscal incentives, (iii) companies that carry out operations in foreign trade and (iv) companies that are bound by tax legislation to this type of taxation.

In the following paragraphs, a simple exercise for a tax accounting case related to a RD\&I project between a company and a ITC is presented. The objective is to determine the tax payable when two situations are considered, when the Law of Good is applied and when it is not. Taxable income is the net income for the period adjusted by additions, exclusions or prescribed compensation or those authorized by Regulation (Decree Law 1,598 / 1977, Article 6).

The exercise is based on the following questions. Whereas a company decided to hire an ICT to conduct a RD\&I project approved by CAPES within the public call referred to in previous chapter, with an annual expenditure of the project to a value of U\$ $1,000,000.00$ (fictitious value), how can the income tax be calculated by using tax incentive requirements and what would be the amount of the deductions in relation to the taxes payable?

In continuing the exercise, the gross margin of U\$50,000,000.00 was obtained subtracting from the gross revenue the costs of sales. The next step is to determine the net income by subtracting the operating and administrative costs, adding to the nondeductible expenses. However, in aiming to determine the net income in case in which the company uses the tax incentives of the Law of Good the expenses with the RD\&I project are then subtracted, differently of trivial cases.

In this exercise, the amounts used are the following: A) the gross margin of the company is $\mathrm{U} \$ 50,000,000.00 ; \mathrm{B})$ operational and administrative costs are $\mathrm{U} \$ 36,500,000.00$; C) non-deductible expenses are U\$100,000.00; and D) the amount contributed to the RD\&I project is U\$ $1,000,000.00$. The calculation of the net income (NI) differently for both situations (i.e. with and without the Law of Good) is derived of the formulas described as follows: 
- Using Law of Good:

\begin{tabular}{|l|l|}
\hline \multicolumn{2}{|c|}{$\mathrm{NI}_{\mathrm{LG}}=\mathrm{A}-\mathrm{B}+\mathrm{C}-\mathrm{D}$. } \\
\hline \begin{tabular}{|l|}
\hline Not using Law of Good: \\
\hline $\mathrm{NI}_{\mathrm{T}}=\mathrm{A}-\mathrm{B}+\mathrm{C}$
\end{tabular} \\
\hline
\end{tabular}

As result, by using the Law of Good, the value considered of the net income is $\$ 12,5$ million, it is unlike in case of non-use of tax incentives in which the considered net income becoming $\$ 13,5$ million.

The next step adjustments are made for calculating the net income value by using the IRS regulation. Applying the Law of Good, some topics such as: D) in expenses, donations, distribution of profits and other requirements are added, making in this exercise the amount of $\$ 1,155,000.00$, including also $E$ ) the financial contribution to the RD\&I project. However, in case of using tax incentives, the expenses with the project are then subtracted, but this does not occur when the Law of Good is not used. Thus, the value of the taxable income is calculated in the period considered.

The calculation of taxable income (IT) for both situations, when the Law of Good is used and when not used, derives from the formulas described as follows:

- Using Law of Good:

$$
\mathrm{TI}_{\mathrm{LG}}=\mathrm{NI}_{\mathrm{LG}}+\mathrm{D}+\mathrm{E}-\mathrm{E} .
$$

- Not using Law of Good:

$$
\mathrm{TI}_{\mathrm{T}}=\mathrm{NI}_{\mathrm{T}}+\mathrm{D}+\mathrm{E}
$$

In this case, with the Law of Good being applied, the value of the taxable income is $\$ 13,655$ million. However, in case of non-use of tax incentives the taxable income is $\$ 14,630$ million.

Following, after determining the taxable income then the Brazilian taxes payable can be determined. It starts with the calculation of the amount of the income tax (IRPJ) to be paid differently for both situations referred above that being derives of the formulas described as follows, and a rate of $15 \%$ is used:

- Using Law of Good:

$$
\operatorname{IRPJ}_{\mathrm{LG}}=\mathrm{TI}_{\mathrm{LG}} \times 0,15
$$

- Not using Law of Good:

$$
\mathrm{IRPJ}_{\mathrm{T}}=\mathrm{TI}_{\mathrm{T}} \times 0,15
$$

Thus, by using the Law of Good, the value of the IRPJ tax is $\$ 2,048,250.00$, on the 
contrary in case of non-use of tax incentives the IRPJ tax is $\$ 2.194,500.00$.

In sequence, according to the IRS regulation the IRPJ tax has an additional amount when the profit value exceeds the value of $\mathrm{R} \$ 20,000.00$ (approximately $\$ 6,000.00$ ). That is, this amount should be added in relation to the twelve months of the year, multiplying by 12 and then applying a rate of $10 \%$. In fact, this value must be subtracted of the taxable income previously determined.

The calculation of the IRPJ Additional tax to be paid differently for both situations is derived of the formula described as follows:

- Using Law of Good:

\begin{tabular}{|c|c|}
\hline $\mathrm{IRPJ}_{\mathrm{LG}}$ Additional $=\left(\mathrm{TI}_{\mathrm{LG}}-(12 \times 6,000.00)\right) \times 0,1$ & (7) \\
\hline \multicolumn{2}{|l|}{ Not using Law of Good: } \\
\hline $\mathrm{IRPJ}_{\mathrm{T}}$ Additional $=\left(\mathrm{TI}_{\mathrm{T}}-(12 \times 6,000.00)\right) \times 0,1$ & (8) \\
\hline
\end{tabular}

This time, using the Law of Good, the value of the IRPJ Additional tax is $\$ 1,341,500.00$, differently in case of non-use of tax incentives then the IRPJ Additional is $\$ 1.439,000.00$.

Combining both amounts then the IRPJ reached the value of $\$ 3,389,770.00$ in case of the use of Law of Good, on the other hand in case of non-use of tax incentives then the IRPJ tax is $\$ 3.663,500.00$. That is, less $\$ 273,730.00$ due to the tax incentive for RD\&I projects.

In addition, the CSLL tax is calculated in a simple way, by using a rate of $9 \%$. The calculation of the tax amount to be paid differently for both situations is derived of the formulas described as follows:

- Using Law of Good:

\begin{tabular}{|l|c|}
\hline \multicolumn{1}{|c|}{$\mathrm{CSLL}_{\mathrm{LG}}=\mathrm{TI}_{\mathrm{LG}} \times 0,09$} & (9) \\
\hline - Not using Law of Good: & (10) \\
\hline \multicolumn{2}{|c|}{$\mathrm{CSLL}_{\mathrm{T}}=\mathrm{TI}_{\mathrm{T}} \times 0,09$} \\
\hline
\end{tabular}

Therefore, using the Law of Good, the value of the CSLL tax is $\$ 1,228,850.00$, it is unlike in the case of non-use of the tax incentives, the CSLL tax is $\$ 1.316,700.00$. That is, less $\$ 87,850.00$ due to the tax incentive for RD\&I projects.

After all these calculations, the amount saved when using the Law of Good is $\$ 243,750.00$ for the $\operatorname{IRPJ}_{\mathrm{LG}}$ and $\$ 87,750.00$ for the $\mathrm{CSLL}_{\mathrm{LG}}$, totaling $\$ 331,500.00$ less in taxes payable. This means $33.15 \%$ benefit over the amount applied in the RD\&I project. On the other side, it is possible to say that the government pays about one-third of the RD\&I project.

Furthermore, in accordance with various simulations for various business real-life situations surveyed, the benefit that can be achieved is between $20.4 \%$ to $34 \%$, and so 
this becomes really motivating for companies to use such tax incentives.

\section{Conclusions}

This letter intended to inform about the relationship between ICTs and companies regarding the application of Law No. 11.196 / 2005, the Law of Good, and to present a practical example regarding booking of expenditure on which was calculated the percentage of tax exemption to which companies can be benefited.

Indeed, by applying this law it was verified that a significant percentage of tax exemption can be obtained, thus motivating companies to perform RD\&I projects, including partnership with public and private ICTs.

Although the accounting procedures performed by companies are more complex than this letter shows, the results was presented in a simple form aiming to demonstrate the utility of such regulation for obtaining tax incentives.

In fact, the Brazilian government has continuously updated laws that improve legislation to motivate research activities and the development of technological innovation. It is noteworthy that recently the regulatory framework concerning Brazilian science and technology environment has been created to complement an existing set of regulations to encourage companies to perform RD\&I projects.

\section{$5 \quad$ References}

Brazil. Public Call MEC/MDIC/MCT 01/2007 - convocam os interessados a apresentar projetos de pesquisa científica tecnológica e de inovação tecnológica. Web site: https://www.capes.gov.br/images/stories/download/bolsas/Edital_2007_MCTMDIC-MEC.pdf. Accessed December 2016.

Brazil. MCTI Annual Report of Tax Incentives Utilization - Base Year 2012. BrasíliaDF. 2013

Brazil. Federal Internal Revenue Service. Normative, Instruction No. 1,187/2011. IRS Web site http://www.normaslegais.com.br/legislacao/in-rfb-1187-2011.htm Accessed December 2016.

Brazil. Law No. 11,487/2007 - inclui dispêndios efetivados em projeto de pesquisa científica e tecnológica e de inovação tecnológica a ser executado pelas instituições Científicas e Tecnológicas - ICT. Government Web site http://www.planalto.gov.br/ccivil_03/_ato2007-2010/2007/lei/111487.htm.

Accessed December 2016.

Brazil. Law No. 11,196/2005 - Institui o Regime Especial de Tributação para a Plataforma de Exportação de Serviços de Tecnologia da Informação - REPES. Government Web site http://www.planalto.gov.br/ccivil_03/_Ato20042006/2005/Lei/L11196.htm. Accessed December 2016.

Frascati Manual (2015), Proposed Standard Practice for Surveys on Research and Experimental Development. OCDE. 